\title{
PUBLICATIONS OF THE DE NOBILI RESEARCH LIBRARY, VIENNA
}

1 George Chemparathy, An Indian Rational Theology. Introduction to Udayana's Nyāyakusumāñjali. Vienna 1972. 202 p. (€ 23.-)

2 Gerhard Oberhammer (ed.), Offenbarung, geistige Realität des Menschen. Arbeitsdokumentation eines Symposiums zum Offenbarungsbegriff in Indien. Wien 1974. 237p. (€ 23.-)

3 Vāsudevāśrama, Yatidharmaprakāás. A Treatise on World Renunciation, critically edited with introduction, annotated translation and appendices by PAtrick Olivelle. Part I: Text. Vienna 1976. 142p. (€ 23.-)

4 Vāsudevāśrama, Yatidharmaprakāás. A Treatise on World Renunciation, critically edited with introduction, annotated translation and appendices by Patrick Olivelle. Part II: Translation. Vienna 1977. 231p. (€ 23.-)

5 Gerhard Oberhammer (ed.), Transzendenzerfahrung, Vollzugshorizont des Heils. Das Problem in indischer und christlicher Tradition. Arbeitsdokumentation eines Symposiums. Wien 1978. 253p. (€ 23.-)

6 Tilmand Vetter, Studien zur Lehre und Entwicklung Śankaras. Wien 1979. 154p. $(€ 23 .-)$

7 Francis X. D'Sa, Śabdaprāmānyam in Śabara und Kumārila. Towards a Study of the Mīmāṃsā Experience of Language. Vienna 1980. 218p. (€ 23.-)

8 Richard F. Young, Resistant Hinduism. Sanskrit Sources on Anti-Christian Apologetics in Early Nineteenth-Century India. Vienna 1981. 200p. (€ 23.-)

9 Gerhard Oberhammer (ed.), Epiphanie des Heils. Zur Heilsgegenwart in indischer und christlicher Religion. Arbeitsdokumentation eines Symposiums. Wien 1982. 256p. (€ 23.-)

10 Gudrun Bühnemann, Budha-Kauśika's Rāmaraksāstotra. A Contribution to the Study of Sanskrit Devotional Poetry. Vienna 1983. 125p. (€ 20.-)

11 Anand Amaladass, Philosophical Implications of Dhvani. Experience of Symbol Language in Indian Aesthetics. Vienna 1984. 240p. (€ 23.-)

12 Paul Hacker $\dagger$, Grundlagen indischer Dichtung und indischen Denkens. Aus dem Nachlaß herausgegeben von KLaus Rưping. Wien 1985. 148p. (€ 21.-)

13 Patrick Olivelle, Renunciation in Hinduism. A Medieval Debate. Vol. 1: The Debate and the Advaita Argument. Vienna 1986. 156p. (€ 26.-)

14 Patrick Olivelle, Renunciation in Hinduism. A Medieval Debate. Vol. 2: The Viśișțādvaita Argument. Vienna 1987. 193p. (€ 26.-)

15 Gudrun Bưnhemann, Pūjā. A Study in Smārta Ritual. Vienna 1988. 253p. (€ 32.-)

16 James W. Laine, Visions of God. Narratives of Theophany in the Mahābhārata. Vienna 1989. 304p. (€ 26.-)

17 Francis X. Clooney, S.J., Thinking Ritually. Rediscovering the Pūrva Mīmāṃsā Experience of Jaimini. Vienna 1990. 293p. (€ 26.-) 
18 Christopher Z. Minkowski, Priesthood in Ancient India. A Study of the Maitrāvaruna Priest. Vienna 1991. 272p. (€ 26.-)

19 Yoshitsugu Sawai, The Faith of Ascetics and Lay Smārtas. A Study of the Sankaran Tradition of Śrngeri. Vienna 1992. 199p. (€ 26.-)

20 F.X. D'S - R. Mesquita (eds.), Hermeneutics of Encounter. Essays in Honour of Gerhard Oberhammer on the Occasion of his $65^{\text {th }}$ Birthday. Vienna 1994. $1+303 p$. $(€ 29 .-)$

21 Max Nıном, Studies in Indian and Indo-Indonesian Tantrism. The Kuñjarakarṇadharmakathana and the Yogatantra. Vienna 1994. 222p. (€ 29.-)

22 R.F. Young - S. Jebanesan, The Bible Trembled. The Hindu-Christian Controversies of Nineteenth-Century Ceylon. Vienna 1995. 204p. (€ 29.-)

23 R.F. Young - G.P.V. Somaratna, Vain Debates. The Buddhist-Christian Controversies of Nineteenth-Century Ceylon. Vienna 1996. 236p. (€ 29.-)

24 R. Mesquita, Madhva und seine unbekannten literarischen Quellen. Einige Beobachtungen. Wien 1997. 151p. (€ 29.-)

25 Kiуotaka Yoshimizu, Der 'Organismus' des urheberlosen Veda. Eine Studie der Niyoga-Lehre Prabhākaras mit ausgewählten Übersetzungen der Bṛhatī. Wien 1997. 430p. $(€ 36 .-)$

26 Thomas Oberlies, Die Religion des Rgveda. Erster Teil - Das religiöse System des Rgveda. Wien 1998. 632p. (€ 67.-)

27 Thomas Oberlies, Die Religion des Rgveda. Zweiter Teil - Kompositionsanalyse der Soma-Hymnen des Rgveda. Wien 1999. 313p. (€ 29.-)

28 Roque Mesquita, Madhva: Viṣnutattvanirnaya. Annotierte Übersetzung mit Studie. Wien 2000. 562p. (€ 56.-)

29 Marcus Schmưcker, Weder als seiend noch als nicht-seiend bestimmbar. Vimuktātmans Lehre von der "Realität" der Welt. Wien 2001. 187p. (€ 19.-)

30 Minoru Hara, Pāśupata Studies. Ed. by Jun Takashima. Vienna 2002. 320p. (€ 32.-)

31 Marzenna Czerniak-Drozdzowicz, Pãñcarattra Scripture in the Process of Change. A Study of the Paramasampitā. Wien 2003. 226p. (€ 23.-)

32 Alex Watson, The Self's Awareness of Itself. Bhatța Rāmakantha's Arguments against the Buddhist Doctrine of No-Self. Wien 2006. 433p. (€ 43.-)

33 Gerhard Oberhammer, Ausgewählte Kleine Schriften. Hrsg. von Utz Podzeit [u.a.]. Wien 2007. 769p. (€ 77.-)

34 Roque Mesquita, Madhvas Zitate aus den Purānas und dem Mahābhārata. Eine analytische Zusammenstellung nicht identifizierbarer Quellenzitate in Madhvas Werken nebst Übersetzungen und Anmerkungen. Wien 2007. 643p. (€ 64.-)

35 Cezary Galewicz, A Commentator in Service of the Empire. Sāyana and the Royal Project of Commenting on the Whole of the Veda. Wien 2010. 327p. (€ 33.-)

36 Himal Trikna, Perspektivismus und Kritik. Das pluralistische Erkenntnismodell der Jainas angesichts der Polemik gegen das Vaiśeșika in Vidyānandins Satyaśāsanaparīkṣā. Wien 2012. 401p. (€ 28.-) 


\section{OCCASIONAL PAPERS}

1 Gerhard Oberhammer - Hans Waldenfels, Überlieferungsstruktur und Offenbarung. Aufriß einer Reflexion des Phänomens im Hinduismus mit theologischen Anmerkungen. Wien 1980. 55p. (€ 5.-)

2 Gerhard Oberhammer (ed.), Inklusivismus. Eine indische Denkform. Wien 1983. 113p. $(€ 10 .-)$

3 Gerhard Oberhammer, Versuch einer transzendentalen Hermeneutik religiöser Traditionen. Wien 1987. 48p. (€ 7.-)

4 Gerhard Oberhammer, 'Begegnung' als Kategorie der Religionshermeneutik. Wien 1989. 60p. $(€ 7 .-)$

5 Gerhard Oberhammer, Offenbarungsgeschichte als Text. Religionshermeneutische Bemerkungen zum Phänomen in hinduistischer Tradition. Wien 1994. 109p. (€ 11.-)

6 Gerhard Oberhammer, Transzendenzerfahrung als absolute Begegnung. Wien 2003. 55p. $(€ 10 .-)$

Distributed by:

Sammlung de Nobili

c/o Department of South Asian, Tibetan and Buddhist Studies, South Asian Studies

University of Vienna

Spitalgasse 2, Hof 2/2.1

A-1090 Vienna

Austria

E-Mail:sdn.istb@univie.ac.at

Homepage: http://www.istb.univie.ac.at/cgi-bin/sdn/sdn.cgi 